\title{
Geology and Archæology of Kharga Oasis, Egypt*
}

THE second season's exploration of the Prehistoric Research Expedition of the Royal Anthropological Institute to Kharga Oasis, Egypt, under Miss G. Caton-Thompson and Miss E. Gardner, was devoted to the further examination of the 'fossil' or dead springs of Pleistocene age, discovered in the first season, which promised a fruitful line of inquiry in palæolithic stratigraphy and palæo-climatic conditions, and the dating of the tufa deposits and sheets of gravel on the eastern scarp.

On the scarp, the oldest deposit of the 'drift' sequence is a massive crystalline tufa, here named the Plateau Tufa to distinguish it from the later Wadi Tufas. It has no fauna or human evidence and provisionally is placed at Plio-Pleistocene. This was followed by a period of great erosion, causing the formation of transverse and longitudinal valleys, again without cultural evidence. The next stage was the filling in of these valleys in their upper reaches with acoumulations of angular breccia, now standing in places as high as 25 metres. This represents a long dry period. On its passing, lower palæolithic man appears on the scene. Rain encouraged vegetation, and the earliest of the Wadi Tufas was formed on the breccia. Unrolled. Acheulean tools have been found, thus dating a tufa deposit in Egypt for the first time. The formation of the plateau gravels belongs to this phase. They also have yielded Acheulean tools.

The fifth episode bridges lower and middle palæolithic. An unrolled Acheuleo-Levallois industry has been found in situ sub-tufa. The plateau gravels were eroded and spread in a secondary sheet ("Exogyra gravels"), also containing a mixed Acheulean and Levallois industry.

The middle palæolithic stage is one of considerable but ultimately decreasing rainfall. Another tufa forms over silts and gravels and the formation of the modern drainage system begins. These tufas also are dated by tool floors beneath them. The implements are the products of a tortoise core industry; but it includes so many forms unrecognised in Mousterian industry that it has been named provisionally "PreSebilian". The mode of formation of the tufa is found to be the ponding up of the primary valleys. Pre-Sebilian man frequented the shores of the pools, as is indicated by the collections of tools made from sub-tufa silts.

In the following period the streams grow weaker, and terrace gravels are formed, dual and triple. In an upper terrace were found Pre-Sebilian tools, and on it, in a bed of silt $0.40 \mathrm{~m}$. in thickness, an Aterian flaking site, indicating a lower upper palæolithic date for the Aterian. Here the physiographic sequence

* "The Royal Anthropological Institute's Prehistoric Expedition to Kharga Oasis, Egypt", by Miss G. Caton-Thompson, Man, June 1932. ends, and man abandoned the wadis and gravel plateaux surrounding them for the Libyan plateaux where occur the Capsian and Capsian-Tardenoisean sites.

The great flint mines discovered in the first season were re-examined and found to be purely of neolithic age, and not of mixed age as was believed at first.

On the depression floor a magnificent collection of five hundred Acheulean hand-axes was discovered, These were in an area not exceeding $30 \mathrm{sq}$. metres. and were in mint condition, but glazed. The glaze was certainly produced by sandy waters in a spring and was not due to desert exposure. The hand-axe types are remarkably varied, normally lanceolate forms predominating. With them were their flake industry and cores. In size the axes range from 21 $\mathrm{cm}$. to miniatures less than $4 \mathrm{~cm}$.

A large fossil spring was excavated to a depth of 9 metres. Interstratified gravels, the lowest at a depth of 4 metres, yielded an abundant tortoise core industry which is not Aterian, but its relation to the Levalloisean and Pre-Sebilian on the scarp is not yet clear.

A Capso-Tardenoisean surface site was discovered on the sandrock deposit sealing a fossil spring. The formation of these sandrocks is the final stage in the history of all the fossil springs, and it may, therefore, be inferred that desert conditions obtained prior to the date provided by the surface site.

The cultural elements of the Kharga neolithic were identified. Hearths were discovered in the capping sandrock. Little holes were pierced in the capping sandrock for the supply of water. The curious stonecapped mounds, standing three to four feet high, have been examined and discovered to be the remains of hearths which had originally been holes sunk in the soil and lined with flat pieces of limestone. Since the hearths were abandoned, desert erosion had lowered the ground level. When the stone lining of the hearths was reached, this acted as a protection to the underlying ground and prevented further erosion, so that in course of time the hearth survived as a mound. This indicates a lowering of the desert surface by as much as $6 \mathrm{ft}$. since neolithic times.

In the matter of general conclusions, it would appear that neither Kharga nor the Fayum is of fluviatile origin, as has been suggested, and earlier views as to the non-existence of a lake in the floor of the depression are confirmed. The deposits formerly attributed to a lacustrine agency are wind-borne loess-like material. There is no dating for this arid period, but it appears to be pre-human.

After neolithic times the Wadi appears to have become uninhabitable and not restored to prosperity until Persian engineers tapped the artesian water bed.

\section{Spectrographic Analysis}

$\mathrm{B}^{\mathrm{T}}$ ULLETINS recently issued by Messrs. Adam Hilger, Ltd., give particulars of recent advances in methods of spectrographic analysis and in apparatus. The first, No. 168, describes a method of analysis originated by Judd Lewis (Chemistry and Industry, $51,271-274 ; 1932$ ) and a range of salts, mixtures called "ratio mixtures", and solutions of high chemical purity under the name of "specpure substances", for use in that scheme of analysis. The method, essentially, is for the determination of elements present in minute proportions, and it applies to all the metals, together with the non-metals silicon, boron, phosphorus, and arsenic. The major con- stituents having been determined by ordinary chemical analysis, each minor constituent is determined approximately as a ratio of one or other of the major constituents by comparison of the spectrograms of the sample containing the metals in the form of sulphates with spectrograms of the specpure ratio mixtures. Finally, from the data thus obtained, the substance is synthesised by means of the ratio solutions, and a spectrographic comparison is made between the specimen and its synthesised counterpart.

According to the scheme, the specimen and the ratio substances are so prepared that the comparisons are conducted throughout with chemically similar sub-

No. 3274, VoL. 130] 
stances. Lewis has worked chiefly with the electric arc, using electrodes of copper, but it is claimed that the principles involved are applicable to spark and flame spectra, and that the analysis can be made on as little as a milligram of metal, mineral, or ashes of animal or vegetable tissues; further, that good approximate results may be obtained in ordinary practice with no more than average experience.

The ratio mixtures are an extension of the wellknown H. S. Brand metals and the R.U. powders detailed in Hilger's booklet No. 94/5. This method, evidently, marks a distinct advance in spectrographic analysis, and it should help to extend the use of the spectrograph in chemical laboratories, in which it is now too rarely employed.

Bulletin No. 169 describes the Müller-Hilger Universal Double Monochromator, which, embodying the principle of double spectroscopic purification, is especially suitable for producing powerful radiations which are strictly monochromatic. The form of construction is original and is the subject of several patents in Great Britain and abroad. Both wave- length setting and focusing are effected simultaneously for the whole instrument by means of a single drum engraved to read in wave-lengths. The optical system is crystallised quartz, and the range of the standard instrument extends from wave-length $0.185 \mu$ in the ultra-violet to $4.0 \mu$ in the infra-red. The relative aperture varies from $F / 4$ for $0.185 \mu$ to $F / 5.8$ for $4 \cdot 0 \mu$. The operative beams are axial and the lenses corrected by means of Hilger's interferometers; so that not only are the isolated parts of the spectrum in accurate focus but also every line throughout the spectrum is of good definition.

Messrs. Adam Hilger, Ltd., have just opened new offices and laboratories at 98 King's Road, adjoining their works. The extensions consist of $4400 \mathrm{sq}$. ft. of office space and $3400 \mathrm{sq}$. ft. of additional laboratory space, providing ample room for departments which recently have been much congested. The optical glass department will now be housed in the space formerly occupied by the offices. There are at present seventeen principal sections in the works, with eleven chief technicians and four heads of departments.

\section{William John Macquorn Rankine}

TN an oration delivered in the University of Glasgow on June 15 at a meeting " in Commemoration of Benefactors ", Sir James Henderson paid a tribute to the memory of Macquorn Rankine, who occupied the chair of engineering from 1855 until his death in 1872. Rankine was once described as " the first really powerful thinker in this country to bring the highest mathematical resources to bear on engineering subjects ", while the late Prof. Archibald Barr said that he ranked as "the greatest Professor of Applied Science who has yet appeared ".

There is a sketch of Rankine's life in the " Dictionary of National Biography ", and another by Tait is included in Rankine's "Miscellaneous Scientific Papers", while an obituary notice by Mayer appeared in NATURE of Jan. 16,1873 , but there is still no complete biography of him. In view of this, Sir James Henderson's tribute, printed in full in the Engineer for June 24, will be read with interest.

Rankine, who was born on-July 5, 1820, died on Dec. 24, 1872, at the early age of fifty-two years, having, however, accomplished an amount of work seldom surpassed by any one. His works on "The Steam Engine " (1859), "Applied Mechanics" (1859), "Civil Engineering" (1862), "Machinery and Millwork" (1869) and other subjects are among the classics of engineering, while to these must be added many scores of scientific memoirs. As a boy of fourteen he read Newton's "Principia" in the original Latin, and at sixteen gained a medal for an essay on "The Undulating Theory of Light"; and in spite of his being trained and his experience as a civil engineer, mathematical physics always made the strongest appeal to him. His work in this direction claimed the chief part of Sir James Henderson's address.

Up to the year 1848, said Sir James, Rankine seems to have been continuously employed as a civil engineer in various schemes, but in that year there occurred a sudden change which it is impossible to explain. The practical civil engineer suddenly becomes the theoretical physicist, and from 1848 until he became professor in 1855, Rankine's energies seem to have been devoted almost entirely to those researches in molecular physics which gained for him the fellowship of the Royal Society in 1853. His early work on this subject was followed by researches in elasticity, hydrodynamics, and thermodynamics. Rankine's contribution to thermodynamics Prof. Tait described as his greatest work. He laid the foundation of the mathematical science as it is known to-day; he applied the second law to heat engines of all kinds, steam engines, air engines, and explosive engines, while in steam engines he introduced the cycle now known as the Rankine-Clausius cycle, which is used as the ideal for engines and refrigerators using vapours as the working substance, and he pointed out that this law is only a particular case of a wider law applic. able to all sciences.

At the conclusion of his address, Sir James endeavoured to recall what manner of man Rankine was, and his remarks helped to emphasise the regret that none of Rankine's contemporaries had written his life.

\section{Utilisation of Empire Timbers}

$A \mathrm{~T}$ a recent meeting of the Royal Society of Arts, Maj. J. R. Cosgrove of the Forest Products Research Laboratory read a paper entitled "Empire Timbers, with special reference to their Uses for Furniture and Decoration" (J. Roy. Soc. Arts, vol. 80, No. 4136, Feb. 26, 1932). In introducing the lecturer, the chairman, Sir Richard Allison, said that the lecture was opportune, since "in all directions British citizens are faced with the demand to "Buy British'. With such a commodity as timber apparently much propaganda is necessary to bring home to potential users the possibilities of Empire supplies, and also the beauties of the many woods available for decorative and furniture purposes." $\mathrm{He}$ added that for several years past the architects at the Office of Works have concentrated entirely on
Empire hardwoods, having satisfied themselves that all their requirements in connexion with buildings can be adequately met by Empire supplies. It is most satisfactory to have such a declaration publicly made, and it would appear to give force to the opinion recently expressed in these columns that the forest services of the Empire require strengthening rather than curtailment, in order to be able to give an answer to the question as to whether supplies of the, at present, mostly unknown timbers could be extracted in sufficient amounts and placed on the markets at an economic price. Without this certainty, it will remain difficult to overcome old-established preferences.

Maj. Cosgrove correctly said that the past few years seem to have caused a profound change of outlook in the people of the British Empire, and with the appeal 